\title{
Geodynamic evolution of the South Variscan Iberian Suture as recorded by mineral transformations
}

\author{
Jorge Figueiras a,*, António Mateus a , Mário A. Gonçalves a , João Waerenborgh ${ }^{\text {b }}$, \\ Paulo Fonseca ${ }^{\mathrm{c}}$

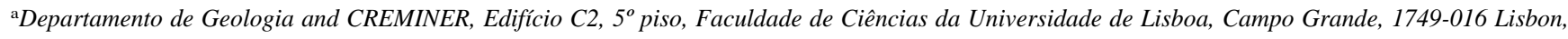 \\ Portugal

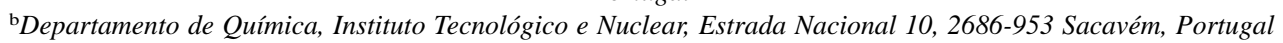 \\ ${ }^{\mathrm{c}}$ Departamento de Geologia and LATTEX, Faculdade de Ciências da Universidade de Lisboa, Campo Grande, Edifício C2, $5^{\circ}$ piso, $1749-016$ Lisbon, \\ Portugal
}

Received 10 July 2001; accepted 15 December 2001

\begin{abstract}
New structural, petrographic, mineralogical and geochemical data from the Beja-Acebuches Ophiolite Complex (BAOC) are presented, and reviewed together with data published elsewhere. The new data obtained shed light on questions such as: 1) the relative importance of the obduction event; 2) its geological record in the deep levels of BAOC; 3) the nature and intensity of the Variscan metamorphism and deformation during subsequent continental (arc) collision; 4) the age relationships between BAOC and the Beja Igneous Complex; and 5) by means of numerical modelling, the thermal metamorphism of the Ossa-Morena autochthonous terranes induced by the ophiolite obduction. The emerging picture is that of a fairly simple overall geological evolution for BAOC, seamlessly integrated within the evolution of the southern branch of the Iberian Variscides. Obduction of BAOC is a relatively minor early event in the general NE-SW convergence that gave rise to the orogen as seen regionally and is recorded by an anisotropic, high-temperature, metamorphic fabric at the gabbro levels and by subtle features of the chemical composition of primary minerals at the underlying peridotite level; it caused chilling of the obducted ophiolitic slab and no significant metamorphism on the autochtonous rocks of the Ossa-Morena Zone. BAOC underwent most of its deformation and (amphibolite facies) metamorphism during a later collisional event, that took place as the most primitive rocks of the Beja Igneous complex were being intruded, and whose waning stages are responsible for extensive serpentinisation of peridotites and for important aquocarbonic fluid discharges along the semibrittle-brittle shear zones meanwhile developed. (C) 2002 Éditions scientifiques et médicales Elsevier SAS. All rights reserved.
\end{abstract}

Keywords: Iberia; Mineral transformations; Ophiolite; Upper Paleozoic; Variscides

\section{Introduction}

The Hesperian Massif of Iberia is one of the most continuous outcrops of the Variscides of Europe and its study is important for the understanding of the southern branch of this orogenic belt. Traditionally, the Iberian Variscides have been divided in several longitudinal geotectonic zones, each characterised by a paleogeographic, tectonometamorphic and magmatic history of its own. Relatively recent studies have shown that the border be-

\footnotetext{
* Corresponding author.

E-mail address: jmvf@fc.ul.pt (J. Figueiras).
}

tween the two southernmost of these zones (the OssaMorena and the South Portuguese Zones) is lined up by a long (circa $130 \mathrm{~km}$ ) and narrow (maximum width $1.5 \mathrm{~km}$ ) belt of mafic and ultramafic rocks, which is currently interpreted as a dismembered and scattered ophiolite complex placed along a suture formed during accretion of the exotic terranes of the South Portuguese Zone onto the autochthonous or parautochthonous terranes now incorporated in the inner zones of the orogenic belt [1,2]. This belt of mafic-ultramafic rocks, known as the Beja-Acebuches Ophiolite Complex (BAOC), is most of the times affected and bounded by WNW-ESE shear zones and/or their late subsidiary structures, whose development can be ascribed to the late stages of continental collision. In the present work, 
structural, petrographic and chemical data collected at or near these tectonic accidents will be presented, and their implications to the post-emplacement evolution of the ophiolite sequence and the suture wherein it occurs will be discussed.

\section{Previous work and geological background}

The current identification of the mafic and ultramafic rock units included in BAOC as an ophiolite complex is not straightforward and stems from geochemical considerations, coupled to lithostratigraphic integration of rocks scattered along the whole length of the belt.

Geochemical data pointing to an 'ophiolitoid' nature of the portuguese part of BAOC rocks were first published by Andrade [3-5] This somewhat controversial initial geochemical evidence has later been supplemented by the work of Munhá et al. [6,7], which improved our understanding of the oceanic geochemical affinities of BAOC and showed that these affinities were shared by rocks outcropping both in Portugal and in Spain (the so-called Acebuches amphibolites). Despite its geochemical affinities, controversy over the ophiolitic nature of BAOC went on, because the lithostratigraphic column normally characterising ophiolites is nowhere to be found. Only after field work summarised by Fonseca and Ribeiro [8] and Quesada et al. [2], did the ophiolitic nature of BAOC gain widespread acceptance, for it has been demonstrated that all rock units normally belonging to ophiolite sequences can be found within BAOC, and that the original spatial relationships of those rock units have been destroyed by the development of several very important longitudinal shear zones, which brought to contact rocks originally far apart from each other in the lithostratigraphic sequence and reduced to one or two the number of rock units to be found at any specific location.

It is now clear that in the eastern (spanish) part of the belt, upper ophiolite sequence rocks predominate, whereas in Portugal gabbros and peridotites are the main rock types present. Examples of sheeted-dyke complexes and of sea floor sediments are rare all over the belt. Their scarcity needs no special explanation for they can easily have been suppressed by tectonic lamination and it is now known that these lithologic types may be absent from some ophiolite sequences. BAOC is not a continuous belt bordering the Ossa-Morena Zone to the South, its outcrops are interrupted for several tens of kilometres by the Ficalho Fault, a seemingly very important ENE-WSW transverse fault still awaiting complete structural characterisation (Fig. 1).

For most of its portuguese length, BAOC runs along the southern border of a large, mostly gabbroic, intrusive complex (the Beja Igneous Complex, BIC [5,9,10]). Both BIC gabbros and BAOC display mineral fabrics with similar directions. Although in BIC the fabrics are carried by the early magmatic mineral suite and in BAOC by a late metamorphic assemblage denoting lower amphibolite/greenschist facies conditions, the geometrical congruence of both fabrics forstered recent [11,12] support of an old [4] hypothesis stating that the Portuguese tract of BAOC is just the southern border of the Beja Igneous Complex deformed in the vicinity of the Ferreira-Ficalho Thrust. The latter is the most important accident of the Southwest Iberia Suture Zone, for it runs continuously (except when interrupted by the Ficalho Fault) between the Tagus and Guadalquivir Cainozoic basins, separating the low grade metasedimentary rocks traditionally ascribed to the South Portuguese Zone to the South from BAOC and the Ossa-Morena Zone to the North.

The northern border of BAOC is most of the times of tectonic origin. It is underlined in Spain by a high grade tectonic mélange ([2] and references therein), but in Portugal the exact nature of the contact is often difficult to assess, due to poor exposure and lack of lithologic contrast between BAOC and BIC. Although in a few instances, the contact of BAOC and BIC can be shown to be intrusive [12], most of the times it is inferred to be tectonic, on the basis of both its straight cartographic expression and steep gravimetric and magnetic gradients showing straight contour lines, observed at the contact location (Instituto Geológico e Mineiro, unpublished maps and reports). BAOC rocks experienced metamorphism, but the apparent metamorphic grade is variable from location to location and may show quite large differences on both sides of the shear zones internally affecting the ophiolite complex. Evidence for high grade metamorphic recrystallisation [2] is sometimes present in the mafic units; low-to-median grade metamorphism is ubiquitous, retrograding the previous high grade mineral assemblages when these are present. Some of the shear zones running along BAOC are associated to extensive carbonate and silica metasomatism.

Quesada et al. [2] have summarised all geological data then available on BAOC. According to them, the geological history of BAOC began as new transitional oceanic crust formed in a marginal basin associated to north-directed subduction of main oceanic lithosphere under the OssaMorena Zone. Soon after magmatic crystallisation, the newly formed oceanic crust was obducted over the OssaMorena Zone (locally represented by a sedimentary sequence capped by a carbonate platform), as testified by $D_{1}$ deformation phase structures [8]. After obduction, the deformation style changed to ESE-WNW thrusting and shear development $\left(\mathrm{D}_{2}\right.$ deformation phase), reflecting the onset of continental (arc?) collision. The final stages of evolution are characterised by SW high angle thrusting reworking former $\mathrm{D}_{2}$ structures. According to the above-mentioned authors, the first metamorphic event recorded in BAOC rocks (coeval with $\mathrm{D}_{1}$ deformation phase) reveals recrystallisation under what they termed low-pressure granulite facies conditions, subsequent metamorphism being a retrogradation of this early high-temperature episode. For a recent review on the subject, see [14]. 


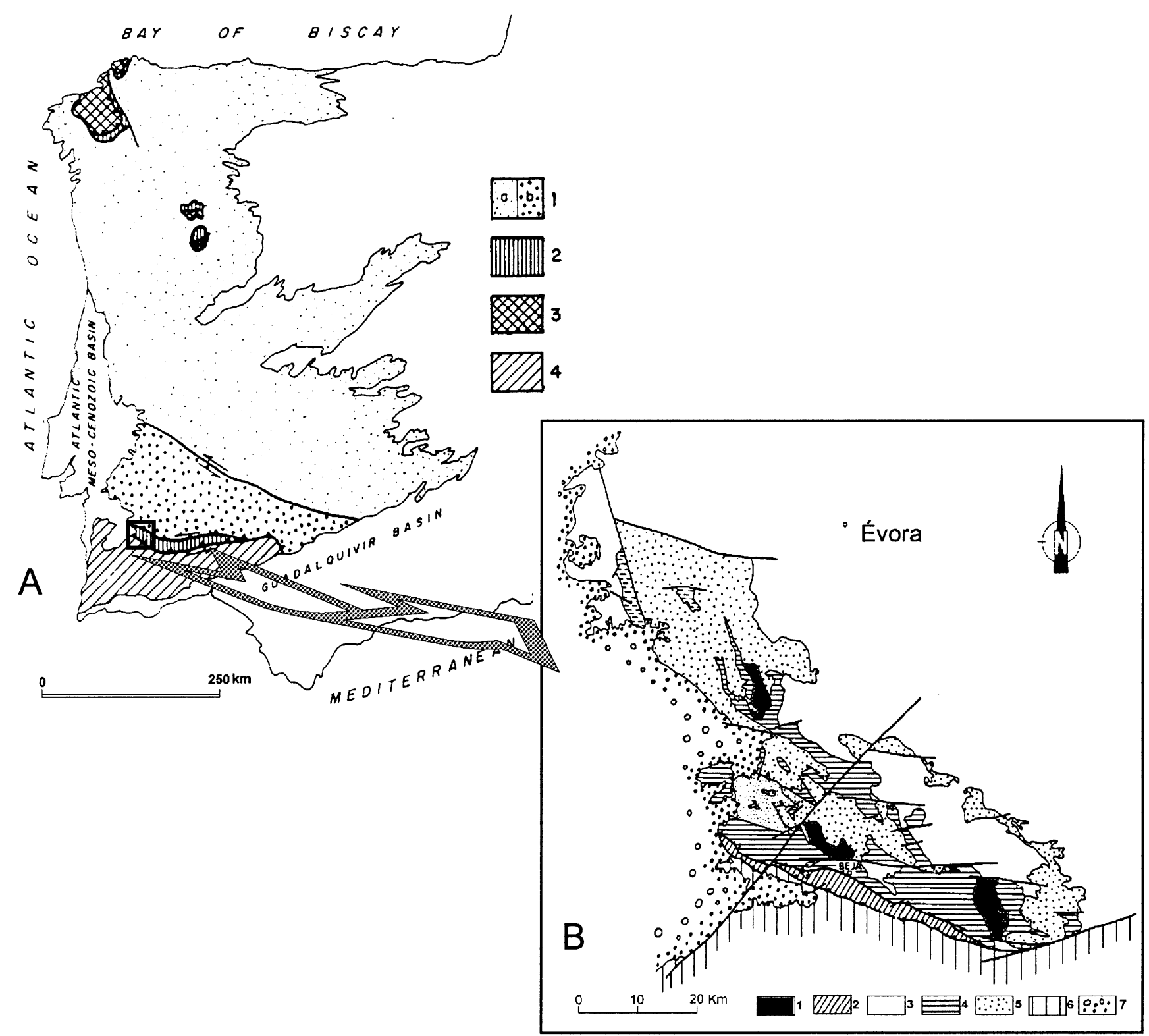

Fig. 1. A. Simplified tectonostratigraphic terrane map of the Iberian Massif (adapted from [28]): 1 - Proterozoic to Upper Paleozoic Iberian Autochthonous Terranes (a. Central Iberian Autochthon; b. Ossa-Morena Autochthon); 2 - Paleozoic Oceanic Terranes; 3 - NW Iberia Continental Allochthonous Terranes; 4 - South Portuguese Terrane. B - Simplified geological map of the Évora-Beja domain (adapted from [2]): 1 - Late Proterozoic to (Lower) Paleozoic imbricated units of the Ossa-Morena Zone; 2 - Mafic and ultramafic rocks of the Beja-Acebuches Ophiolite Complex; 3 - Paleozoic autochthonous rocks of Ossa-Morena Zone; 4 - Mafic and intermediate plutonic rocks of the Beja Igneous Complex; 5 - Acid plutonic and subvolcanic rocks of the Beja Igneous Complex; 6 - Pulo do Lobo metasedimentary group; 7 - Cenozoic sedimentary deposits.

\section{Data summary}

\subsection{Petrography}

Overall, peridotites do not occupy large areas within BAOC and occur mainly near major shear zones, amid regions where gabbroic rocks prevail. Because of their close association to the main tectonic accidents, these rocks are strongly affected by metasomatic and mineralogical transformations induced by late fluid circulation along the shear zones. The peridotites of BAOC underwent most of the times extensive polyphasic serpentinisation, but the usual presence of relics of $\mathrm{Cr}$-spinel, $\mathrm{Mg}$-rich olivine, enstatite and, sometimes, diopside, strongly suggests harzburgite as the original rock. However, in some places, only spinel relics are observed and this is taken to point to a dunitederived serpentinite. Rare wehrlites/troctolites are also known from the same general tectonic setting of BAOC ultramafic rocks; they show incomplete serpentinisation and, besides abundant $\mathrm{An}_{70}$ plagioclase, significant amounts 
of disseminated sulphides, mainly pentlandite and pyrrhotite; their original relationships with the rest of the peridotites are presently unclear.

Gabbroic rocks outcropping in Portugal are mostly gabbros and gabbronorites, composed of $\mathrm{An}_{51}-\mathrm{An}_{60}$ plagioclase, relics of diopside, brown Na- and Ti-bearing hornblende, ilmenite, titanium-rich magnetite and some sulphides (mostly pyrrhotite, chalcopyrite and pyrite); badly preserved relics of olivine are sometimes observed. These rocks are metamorphosed in a transitional greenschistamphibolite facies, whose typical mineral assemblage, albite + oligoclase + actinolite + pale-brown to green hornblende + epidote + chlorite + sphene [2], is particularly well developed in the uppermost section of the ophiolite sequence. In deeper-lying rocks, this metamorphic episode is represented by the transformation of primary pyroxene and amphibole to green hornblende and actinolite, by quartz \pm chlorite deposition and by the development of reaction rims of untwinned plagioclase around earlier deformed crystals of this mineral; these mineral transformations may obliterate evidence for an earlier syntectonic recrystalisation event under very high temperatures (800$900^{\circ} \mathrm{C}$ ) and pressures under $5 \mathrm{kbar}$, as attested by the presence of Ca-plagioclase, olivine, ortho- and clinopyroxene and by the absence of coronitic garnet-spinel around plagioclase [2]. In thin section, these rocks show several superimposed deformation and metasomatic events. Plagioclase grains are commonly interlocking and show bent or kinked twin lamellae, deformation bands, wavy extinction and segregation bands; evidence for plagioclase subgrain development or annealing was not detected. The observed twinning is believed to be of mechanical origin, since twin bands commonly wedge out within the grains and are sometimes restricted to the margins of the grains in places where stress concentration might be expected. In rocks affected by the regional shear zones, plagioclase crystals show cataclasis and later saussuritisation, whereas quartz display strong plastic deformation followed by dynamic recrystallisation.

In BAOC, metasomatism and hydrothermal alteration decrease as a function of distance to the main shear zones affecting the complex. The shear zones themselves are underlined by relatively thin belts (width $10-20 \mathrm{~m}$ ) of very strong carbonatisation, usually accompanied by significant silicification, which can be seen to wane outwards towards rocks progressively less affected by carbonate or silica deposition. The very serpentinisation, although ubiquitous, seems to increase towards the accidents, whenever adequate data and/or exposure exist.

In general, the mineral transformations that occurred along the major shear zones can be described as a(an almost) complete breakdown of the primary minerals and their substitution by a secondary assemblage comprising carbonates (mostly dolomite + ankerite, sometimes also siderite, magnesite and calcite), microcrystalline quartz, chlorite, rare pyrite grains and some ill-crystallised iron and titanium oxides. The more resistant primary minerals (chrom spinel and ilmenite + plagioclase in the case of peridotites and gabbros, respectively) are commonly preserved, and the lithologic nature of the protolith causes differences in the secondary mineral assemblages, which include, for peridotites, serpentine \pm magnesite, with textures showing that carbonatisation postdates serpentinisation, and leucoxene \pm sericite \pm siderite, for gabbroic rocks. Moreover, when (relatively late) polyphasic veins are present within the strongly carbonatised domains, it can be seen that their earliest infillings depend on the host lithology, being predominantly sideritic when hosted by mafic rocks and silicic or dolomitic when hosted by peridotites. The final stages of carbonate deposition are invariably represented by veins and vugs filled by coarse, sparry calcite.

The sequence of mineral transformations having occurred along the major shear zones can be studied at some distance from them, where the original (more or less serpentinised) rocks are still partially preserved. In the peridotites, incipient carbonatisation enhanced the formation of ferritchromite \pm magnetite reaction rims around chromspinel grains, which had begun during prior serpentinisation. In the gabbroic rocks, this initial stage of alteration leads to decomposition of the mafic minerals and to the precipitation of chlorite. The onset of strong carbonatisation is marked by the inception of felsic silicate decomposition, all silicate minerals (including serpentine) being replaced by fine-grained isotropic aggregates of dolomite and ankerite ( \pm siderite, in the case of gabbroic rocks), by sulphide oxidation and by deposition of significant amounts of silica as micrometric (often corroded) quartz, probably a by-product of serpentine decomposition; millimetric vugs filled with quartz testify a late silicification.

\subsection{Whole rock geochemistry}

Average chemical compositions of non-metasomatised BAOC lithologic types are quoted in Table I, together with the variation range observed for each chemical element.

Despite of the presence of rocks that are petrographically classified as wehrlites/troctolites and as primitive gabbros, rocks of intermediate composition between the two groups just mentioned are very rare (Fig. 2).

Peridotites are characterised by the presence of a clear differentiation trend, which is shown by variable (and low) alumina concentrations positively correlated with such chemical components as $\mathrm{Na}_{2} \mathrm{O}$ and $\mathrm{CaO}$ and negatively correlated with $\mathrm{MgO}$ and $\mathrm{Ni}$. In this group, $\mathrm{Ti}$ concentrations are low and independent of the alumina contents, whereas $\mathrm{V}$ has quite variable values, poorly correlated with $\mathrm{Al}_{2} \mathrm{O}_{3}$. The differentiation trend of the ultramafic rocks is also well expressed in their minor elements concentrations, with $\mathrm{Cr}$ and $\mathrm{Co}$ co-varying with $\mathrm{Ni}$, and $\mathrm{V}$ and $\mathrm{Zr}$ with $\mathrm{Ti}$. As expected, iron and Ti are totally uncorrelated, as are also $\mathrm{Cu}$ and $\mathrm{Ni}$. 
Table I

Representative analyses of non-metasomatised BAOC rocks.

\begin{tabular}{|c|c|c|c|c|c|c|}
\hline & \multicolumn{3}{|l|}{ Peridotites } & \multicolumn{3}{|c|}{ Gabbroic rocks } \\
\hline & AZM1 & FA-13 & $\mathrm{n}=8(*)$ & STP15 & MAC2 & $\mathrm{n}=7(*)$ \\
\hline \multicolumn{7}{|l|}{$\mathrm{Wt} \%$} \\
\hline $\mathrm{SiO} 2$ & 37.71 & 35.60 & $(35.51-39.93)$ & 46.49 & 49.15 & $(44.08-56.98)$ \\
\hline $\mathrm{A} 12 \mathrm{O} 3$ & 8.68 & 0.97 & $(0.97-8.73)$ & 18.82 & 20.07 & $(10.24-20.07)$ \\
\hline $\mathrm{Fe} 2 \mathrm{O} 3$ & 9.21 & 17.39 & $(9.21-17.39)$ & 7.36 & 7.46 & $(7.10-12.08)$ \\
\hline $\mathrm{MnO}$ & 0.13 & 0.19 & $(0.13-0.19)$ & 0.12 & 0.14 & $(0.11-0.17)$ \\
\hline $\mathrm{MgO}$ & 28.90 & 34.43 & $(27.38-36.71)$ & 4.36 & 5.67 & $(4.36-11.65)$ \\
\hline $\mathrm{CaO}$ & 4.04 & 0.77 & $(0.12-5.12)$ & 12.87 & 9.58 & $(7.00-12.87)$ \\
\hline $\mathrm{Na} 2 \mathrm{O}$ & 0.41 & 0.04 & $(0.01-0.81)$ & 2.84 & 3.72 & $(2.40-4.98)$ \\
\hline $\mathrm{K} 2 \mathrm{O}$ & 0.01 & 0.01 & $(0.01-0.81)$ & 0.12 & 0.47 & $(0.12-0.62)$ \\
\hline $\mathrm{TiO} 2$ & 0.08 & 0.08 & $(0.07-0.31)$ & 2.29 & 1.90 & $(0.83-3.54)$ \\
\hline $\mathrm{P} 2 \mathrm{O} 5$ & 0.01 & 0.01 & $(0.01-0.07)$ & 0.26 & 0.07 & $(0.02-0.26)$ \\
\hline LOI & 10.81 & 10.71 & $(7.94-13.62)$ & 3.16 & 1.92 & $(1.92-8.34)$ \\
\hline Total & 99.99 & 100.20 & & 98.69 & 100.15 & \\
\hline \multicolumn{7}{|l|}{$\%$} \\
\hline $\mathrm{S}$ & 0.040 & 0.155 & $(0.02-0.16)$ & 0.068 & 0.010 & $(0.01-0.07)$ \\
\hline $\mathrm{C}$ & 0.325 & 0.094 & $(0.06-0.33)$ & 0.578 & 0.239 & $(0.15-1.51)$ \\
\hline \multicolumn{7}{|l|}{ Ppm } \\
\hline $\mathrm{Ba}$ & 10 & 3 & $(3-78)$ & 69 & 165 & $(64-258)$ \\
\hline $\mathrm{Sr}$ & 89 & 9 & $(2-136)$ & 364 & 437 & $(100-437)$ \\
\hline $\mathrm{Y}$ & 1 & 2 & $(1-6)$ & 7 & 6 & $(6-38)$ \\
\hline $\mathrm{Zr}$ & 5 & 6 & $(5-23)$ & 9 & 10 & $(9-291)$ \\
\hline $\mathrm{V}$ & 15 & 18 & $(5-58)$ & 422 & 314 & $(164-595)$ \\
\hline $\mathrm{Cu}$ & 33 & 62 & $(33-97)$ & 38 & 17 & $(11-38)$ \\
\hline $\mathrm{Zn}$ & 31 & 78 & $(31-78)$ & 37 & 36 & $(36-54)$ \\
\hline $\mathrm{Ni}$ & 1286 & 1217 & $(759-2181)$ & 24 & 21 & $(13-143)$ \\
\hline $\mathrm{Co}$ & 108.0 & 133.0 & $(96.7-148.0)$ & 44.0 & 43.7 & $(32.9-70.5)$ \\
\hline $\mathrm{Cr}$ & 2210.0 & 1180.0 & $(1180-3620)$ & 74.9 & 45.0 & $(40.9-235.0)$ \\
\hline $\mathrm{Sc}$ & 6.9 & 9.4 & $(6.4-13.5)$ & 37.3 & 36.3 & $(28.6-67.2)$ \\
\hline W & 54 & 8 & $(6-54)$ & 109 & 121 & $(41-227)$ \\
\hline $\mathrm{La}$ & 0.3 & 0.3 & $(0.2-2.3)$ & 3.8 & 2.8 & $(2.8-38.5)$ \\
\hline $\mathrm{Ce}$ & 1 & 1 & $(1-6)$ & 9 & 7 & $(7-58)$ \\
\hline $\mathrm{Nd}$ & 1 & 1 & $(1-3)$ & 5 & 4 & $(4-21)$ \\
\hline $\mathrm{Sm}$ & 0.14 & 0.19 & $(0.14-0.88)$ & 1.28 & 0.96 & $(0.96-5.44)$ \\
\hline $\mathrm{Eu}$ & 0.14 & 0.08 & $(0.08-0.70)$ & 0.79 & 0.96 & $(0.59-1.58)$ \\
\hline $\mathrm{Tb}$ & 0.1 & 0.1 & $(0.2-0.5)$ & 0.2 & 0.2 & $(0.2-1.8)$ \\
\hline $\mathrm{Yb}$ & 0.17 & 0.23 & $(0.17-0.70)$ & 0.74 & 0.72 & $(0.74-2.48)$ \\
\hline $\mathrm{Lu}$ & 0.03 & 0.03 & $(0.03-0.11)$ & 0.11 & 0.11 & $(0.11-0.52)$ \\
\hline
\end{tabular}

* total number of analysed samples and respective range of analytical data for each oxide or element

As is the case for most ophiolitic sequences, BAOC is quite poor in rocks more silicic than gabbros or basalts. According to this, its mafic rocks show no discernible differentiation trend when its major element compositions are examined. This is however not true for minor element compositions, where some trends involving $\mathrm{Ni}, \mathrm{Cr}, \mathrm{Ti}, \mathrm{V}$ and, to some extent, also $\mathrm{Zr}$, span both gabbroic rocks and peridotites without any break, which is remarkable given the presence of a very distinct gap in major element concentrations between both types of rocks (Fig. 3).

Many of the covariant trends of BAOC rocks are readily explained by their mineralogy. For instance, the outstanding Ti-V correlation in gabbroic rocks is mainly caused by ilmenite accumulation and the co-variance of $\mathrm{Ni}$ and $\mathrm{Cr}$ in the peridotites is due to the simultaneous presence of Cr-spinel and sulphides (mainly pentlandite + pyrrhotite) or Ni-bearing olivine.
In BAOC, amphibolites and evolved gabbros display parallel REE normalised patterns, showing small negative $\mathrm{Eu}$ anomalies, which, coupled to evident $\mathrm{Sr}$ depletions, indicate crystallisation from a liquid having previously precipitated plagioclase and/or clinopyroxene under reducing conditions. Indirect support to this interpretation comes from the observation that primitive gabbros within BAOC are enriched in both $\mathrm{Ba}$ and $\mathrm{Sr}$ and have large positive $\mathrm{Eu}$ anomalies. REE patterns of peridotites display a more or less distinct positive Eu anomaly, but their interpretation is not straightforward, since they may result from the presence of earlier plagioclase (observed in wehrlites/troctolites but impossible to prove for wholly serpentinised rocks) or from the serpentinisation process itself, e.g. 15,16]

That BAOC is not a typical mid ocean ridge igneous complex is indicated by the fact that many of its basic rocks have $\mathrm{Zr}$ concentrations around $100 \mathrm{ppm}$, which, according 

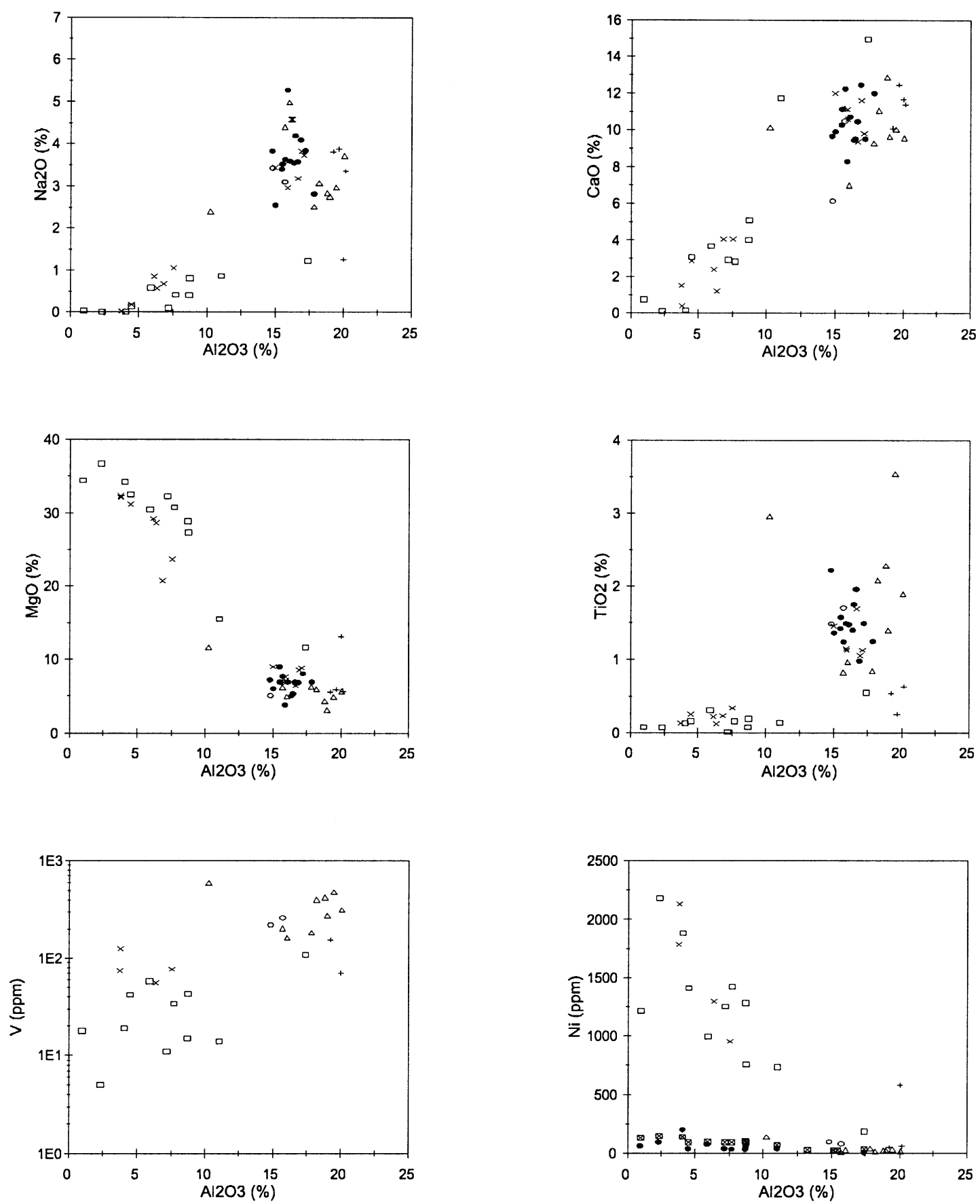

Fig. 2. Major elements whole-rock composition of BAOC rocks. Open squares, ultramafic rocks; cross signs, idem retrieved from [5], open triangles, metagabbros; plus signs, metagabbros retrieved from [5] black dots, amphibolites retrieved from [5] and [2]; open hourglasses metabasalts retrieved from [2].

to Pearce and Cann [17], suggests an environment more similar to a marginal oceanic arc than to a typical spreading ridge. The same is shown by the plots $\mathrm{Ti}-\mathrm{V}, \mathrm{Zr} / \mathrm{Y}-\mathrm{Zr}$ and $\mathrm{Ni}-\mathrm{Ti} / \mathrm{Cr}$ (Fig. 3), where the points representing BAOC rocks consistently fall within or at the margins of the field occuppied by island arc basalts [18,19,20].

The metasomatic processes that occurred along the main shear zones affecting BAOC (mainly carbonatisation and silicification) have resulted in a general leaching of most of the major elements of the original rocks ( $\mathrm{Ca}$ being the outstanding exception) but have preserved to some extent the original chemical signature of the rocks as displayed by their minor element compositions. Examples of this are the high and positively correlated $\mathrm{Ti}$ and $\mathrm{V}$ concentrations displayed by altered rocks derived from gabbros and the high values of $\mathrm{Cr}, \mathrm{Ni}, \mathrm{Co}$, and often also $\mathrm{Cu}$, found when the 

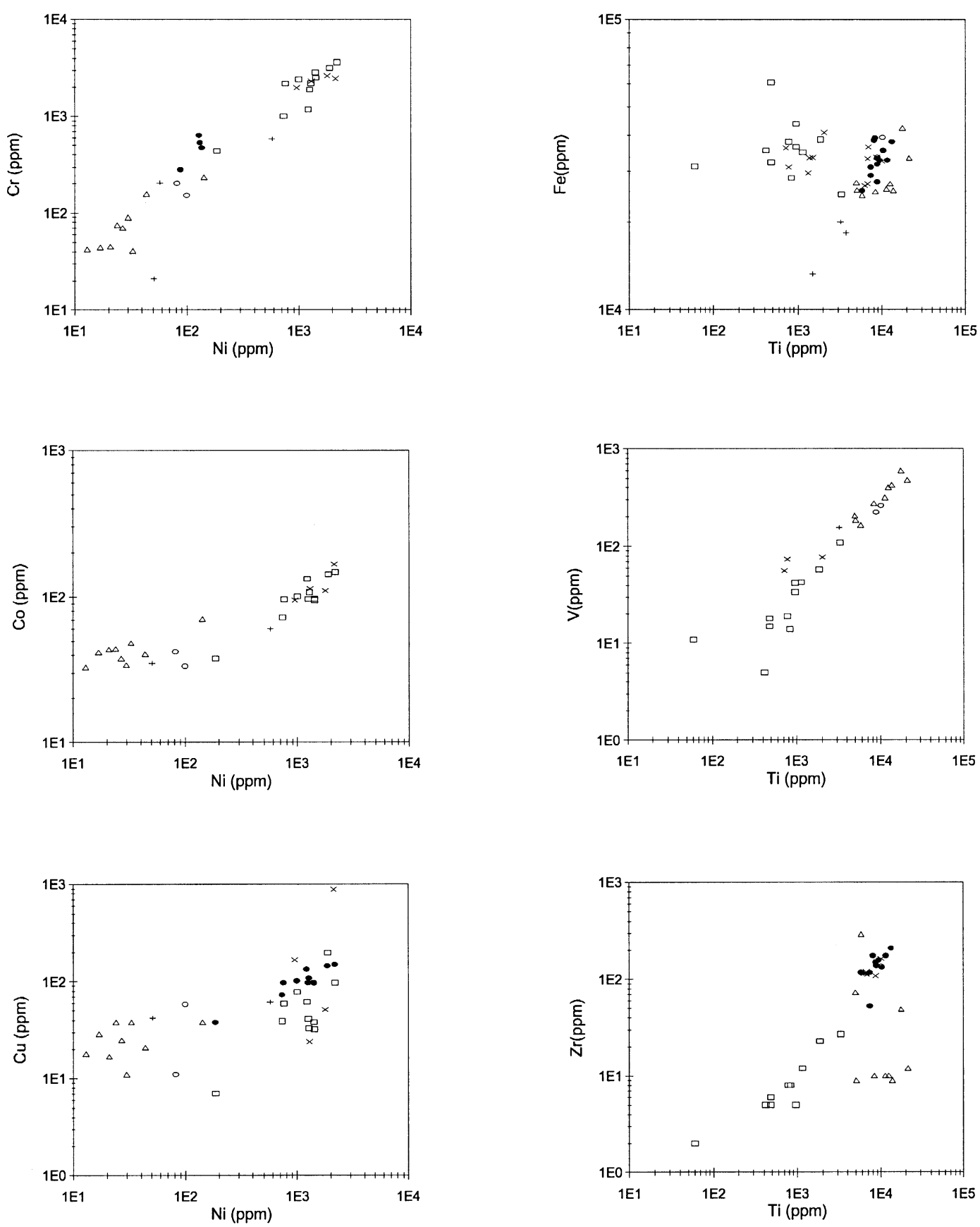

Fig. 3. Minor elements whole-rock composition of BAOC rocks. Symbols as in Fig. 2.

metasomatised rock derives from an ultramafic protolith. A detailed discussion of the metasomatic processes in BAOC shear zones can be found in Mateus et al. 21].

\subsection{Mineral chemistry}

Tables Ш and $Ш$ report representative analyses of BAOC primary and secondary minerals, respectively. In nonmetasomatised rocks, minerals other than Cr-bearing spinel have slightly variable chemical compositions but no significant zonation is observed in any of the minerals present.
Olivine compositions are quite homogeneous throughout but two different types can be distinguished on the basis of their Ni contents: olivines coexisting with abundant orthopyroxene and/or with high-temperature Ni-bearing sulphide minerals are depleted in $\mathrm{Ni}$ when compared with olivines occurring in other contexts.

Spinels (other than magnetite) in BAOC are restricted to peridotites and wehrlites/troctolites. In the diagram $\mathrm{Cr} /(\mathrm{Cr}+\mathrm{Al})-\mathrm{Fe} /(\mathrm{Fe}+\mathrm{Mg})$ (Fig. 4) they plot distinctly to the right of the main spinel compositional trend seen in the data compiled by Roeder [22] and also to the right of the 
Table II

Representative chemical analyses for different primary mineral species (expressed as oxide wt\%) and cation proportions.

\begin{tabular}{|c|c|c|c|c|c|c|c|c|c|c|c|c|c|c|c|c|c|c|c|c|}
\hline & \multicolumn{3}{|c|}{ Olivines } & \multicolumn{3}{|c|}{ Pyroxenes } & \multicolumn{4}{|c|}{ Amphiboles } & \multicolumn{3}{|c|}{ Plagioclases } & \multicolumn{4}{|c|}{ Spinels } & \multicolumn{3}{|c|}{ Ilmenites } \\
\hline & AZM1 & PLM5 & $N=18$ & PLM2 & STP15 & $\mathrm{N}=15$ & PLM4 & MEL11 & $1 \mathrm{MAC} 2$ & $2 \mathrm{~N}=11$ & STP13 & MAC4 & $\mathrm{N}=18$ & AZM2 & PLM2 & FA1 & $\mathrm{N}=19$ & MAC4 & STP15 & $\mathrm{N}=10$ \\
\hline & & & $n=85$ & & & $n=45$ & & & & $n=34$ & & & $n=115$ & & & & $n=121$ & & & $n=77$ \\
\hline $\mathrm{SiO} 2$ & 39.85 & 39.51 & $(38.17-40.56)$ & 54.89 & 51.99 & $(51.20-54.84)$ & 41.88 & 42.24 & 47.67 & $(41.67-49.29)$ & 53.00 & 54.29 & $(47.33-55.24)$ & & & & & & & \\
\hline $\mathrm{TiO} 2$ & 0.02 & 0.00 & $(0.00-0.04)$ & 0.34 & 0.43 & $(0.20-0.60)$ & 3.46 & 1.70 & 1.37 & $(0.55-3.46)$ & & & & 0.37 & 0.01 & 0.52 & $(0.00-2.28)$ & 48.44 & 43.18 & $(39.28-49.28)$ \\
\hline $\mathrm{A} 12 \mathrm{O} 3$ & 30.00 & 0.00 & $(0.00-0.02)$ & 1.18 & 1.99 & $(1.18-2.38)$ & 11.61 & 8.14 & 7.15 & $(6.11-13.92)$ & 28.93 & 29.13 & $(27.32-32.08)$ & 30.25 & 33.67 & 27.35 & $(20.75-44.84)$ & & & \\
\hline $\mathrm{V} 2 \mathrm{O} 3$ & & & & & & & & & & & & & & 0.20 & 0.05 & 0.32 & $(0.04-0.48)$ & 1.83 & 2.44 & $(1.09-2.98)$ \\
\hline $\mathrm{Cr} 2 \mathrm{O} 3$ & & & & 0.25 & 0.03 & $(0.00-0.32)$ & 1.43 & 0.07 & 0.02 & $(0.00-1.87)$ & & & & 31.39 & 29.67 & 31.28 & $(10.17-35.04)$ & & & \\
\hline $\mathrm{MgO}$ & 46.02 & 44.69 & (40.10-46.99) & 30.34 & 13.93 & $(13.51-31.00)$ & 15.82 & 11.34 & 14.35 & (11.34-16.56) & & & & 12.32 & 9.74 & 7.49 & $(6.37-13.47)$ & 0.10 & 0.05 & $(0.01-1.13)$ \\
\hline $\mathrm{CaO}$ & 0.00 & 0.02 & $(0.00-0.04)$ & 1.53 & 22.30 & $(0.39-22.92)$ & 10.72 & 10.35 & 11.26 & $(10.13-14.55)$ & 12.46 & 11.15 & $(10.20-15.72)$ & & & & & & & \\
\hline $\mathrm{MnO}$ & 0.16 & 0.19 & $(0.10-0.30)$ & 0.20 & 0.16 & $(0.16-0.25)$ & 0.10 & 0.18 & 0.22 & $(0.08-0.32)$ & & & & 0.30 & 0.31 & 0.38 & $(0.23-0.59)$ & 1.94 & 0.65 & $(0.00-2.67)$ \\
\hline $\mathrm{FeO}$ & 13.08 & 14.36 & $(11.55-19.90)$ & 9.41 & 8.82 & $(4.88-10.18)$ & 6.35 & 15.56 & 13.34 & $(4.96-15.56)$ & 0.31 & 0.29 & $(0.00-0.65)$ & 23.16 & 24.97 & 30.12 & (19.19-38.29) & 43.25 & 52.35 & $(41.65-52.35)$ \\
\hline $\mathrm{NiO}$ & 0.33 & 0.14 & $(0.14-0.33)$ & 0.04 & 0.00 & $(0.00-0.04)$ & & & & & & & & 0.16 & 0.10 & 0.13 & $(0.00-0.51)$ & & & \\
\hline $\mathrm{ZnO}$ & & & & & & & & & & & & & & 0.16 & 0.46 & 0.35 & $(0.00-0.67)$ & & & \\
\hline $\mathrm{Na} 2 \mathrm{O}$ & & & & 0.05 & 0.34 & $(0.01-0.39)$ & 2.98 & 1.30 & 1.26 & $(1.04-3.10)$ & 4.39 & 4.80 & $(1.04-3.10)$ & & & & & & & \\
\hline $\mathrm{K} 2 \mathrm{O}$ & & & & 0.00 & 0.00 & $(0.00-0.01)$ & 0.40 & 0.30 & 0.20 & $(0.18-0.48)$ & 0.17 & 0.12 & $(0.01-0.32)$ & & & & & & & \\
\hline $\begin{array}{l}\text { Total } \\
\S\end{array}$ & 99.46 & 98.92 & & 98.24 & 100.00 & & 94.75 & 91.19 & 96.84 & & 99.25 & 99.78 & & 98.31 & 98.98 & 97.94 & & 95.56 & 98.67 & \\
\hline $\mathrm{Si}$ & 1.00 & 1.00 & & 1.96 & 1.93 & & 6.23 & 6.74 & 7.02 & & 9.68 & 9.81 & & & & & & & & \\
\hline $\mathrm{Ti}$ & 0.00 & 0.00 & & 0.01 & 0.01 & & 0.39 & 0.20 & 0.15 & & & & & 0.07 & 0.00 & 0.10 & & 1.91 & 1.64 & \\
\hline $\mathrm{Al}$ & 0.00 & 0.00 & & 0.05 & 0.09 & & 2.04 & 1.53 & 1.24 & & 6.23 & 6.20 & & 8.61 & 9.59 & 8.15 & & & & \\
\hline V & 0.00 & 0.00 & & & & & 0.00 & 0.00 & 0.00 & & & & & 0.04 & 0.01 & 0.06 & & 0.08 & 0.10 & \\
\hline $\mathrm{Cr}$ & 0.00 & 0.00 & & 0.01 & 0.00 & & 0.17 & 0.01 & 0.00 & & & & & 6.00 & 5.67 & 6.25 & & & & \\
\hline $\mathrm{Fe} 3+$ & & & & & & & & & & & 0.05 & 0.04 & & 1.27 & 0.71 & 1.42 & & 0.08 & 0.60 & \\
\hline $\mathrm{Mg}$ & 1.72 & 1.69 & & 1.62 & 0.77 & & 3.51 & 2.70 & 3.15 & & & & & 4.44 & 3.51 & 2.82 & & 0.01 & 0.00 & \\
\hline $\mathrm{Ca}$ & 0.00 & 0.00 & & 0.06 & 0.89 & & 1.71 & 1.77 & 1.78 & & 2.44 & 2.16 & & & & & & & & \\
\hline $\mathrm{Mn}$ & 0.00 & 0.00 & & 0.01 & 0.01 & & 0.01 & 0.02 & 0.03 & & & & & 0.06 & 0.06 & 0.08 & & 0.09 & 0.03 & \\
\hline $\mathrm{Fe} 2+$ & 0.27 & 0.30 & & 0.28 & 0.27 & & 0.79 & 2.08 & 1.64 & & & & & 3.41 & 4.34 & 4.94 & & 1.88 & 1.61 & \\
\hline $\mathrm{Ni}$ & 0.01 & 0.00 & & 0.00 & 0.00 & & 0.01 & 0.00 & 0.00 & & & & & 0.03 & 0.02 & 0.03 & & & & \\
\hline $\mathrm{Zn}$ & 0.00 & 0.00 & & & & & 0.00 & 0.00 & 0.00 & & & & & 0.03 & 0.08 & 0.06 & & & & \\
\hline $\mathrm{Na}$ & 0.00 & 0.00 & & 0.00 & 0.02 & & 0.86 & 0.40 & 0.36 & & 1.55 & 1.68 & & & & & & & & \\
\hline K & 0.00 & 0.00 & & 0.00 & 0.00 & & 0.08 & 0.06 & 0.04 & & 0.04 & 0.03 & & & & & & & & \\
\hline $\begin{array}{l}\text { Total } \\
\text { cations }\end{array}$ & $\begin{array}{l}3.00 \\
\text { s }\end{array}$ & 3.00 & & 4.00 & 4.00 & & 15.78 & 15.52 & 15.41 & & 19.98 & 19.92 & & 23.96 & 23.99 & 23.41 & & 4.05 & 3.98 & \\
\hline
\end{tabular}

$\S$ Calculations on the basis of: 3 cations for olivine; 4 cations for pyroxenes and ilmenites; (15-Na,K) or (13-K,Na,Ca) cations for amphiboles and 32 oxygens for plagioclases and spinels. $\mathrm{N}=$ number of examined samples; $n=$ number of analyses 
Table III

Representative chemical analyses for different secondary mineral species (expressed as oxide wt\%) and cation proportions.

\begin{tabular}{|c|c|c|c|c|c|c|c|c|c|c|c|c|c|c|c|c|}
\hline & \multicolumn{3}{|c|}{ Amphiboles } & \multicolumn{3}{|c|}{ Chlorites } & \multicolumn{3}{|c|}{ Plagioclases } & \multicolumn{3}{|l|}{ Spinels } & \multicolumn{4}{|l|}{ Ti-0xides } \\
\hline & MAC1 & AZM13 & $\mathrm{N}=10$ & PLM2 & MEL17A & $\mathrm{N}=14$ & MAC7 & AZM9 & $N=18$ & AZM10 & STP10A1 & $\mathrm{N}=5$ & AZM12 & MAC4 & STP14 & $\mathrm{N}=12$ \\
\hline & & & $n=33$ & & & $n=42$ & & & $n=44$ & & & $n=28$ & & & & $n=52$ \\
\hline $\mathrm{SiO} 2$ & 54.18 & 55.15 & $(42.40-56.92)$ & 29.94 & 26.49 & $(25.45-33.87)$ & 64.37 & 55.60 & $(53.00-64.85)$ & & & & & & & \\
\hline $\mathrm{TiO} 2$ & 0.34 & 0.18 & $(0.00-0.64)$ & 0.02 & 0.02 & $(0.00-0.15)$ & & & & 0.46 & 2.00 & $(0.29-3.97)$ & 69.67 & 24.70 & 79.34 & $(24.70-93.81)$ \\
\hline $\mathrm{Al} 2 \mathrm{O} 3$ & 2.07 & 1.19 & $(0.28-23.94)$ & 17.65 & 20.02 & $(8.92-24.70)$ & 21.57 & 28.08 & $(21.56-29.69)$ & 1.30 & 0.67 & $(0.67-13.28)$ & & & & \\
\hline V2O3 & & & & & & & & & & 0.18 & 0.37 & $(0.11-0.78)$ & 4.46 & 1.20 & 4.18 & $(0.84-5.30)$ \\
\hline $\mathrm{Cr} 2 \mathrm{O} 3$ & 0.00 & 0.02 & $(0.00-0.06)$ & 0.00 & 0.00 & $(0.00-0.34)$ & & & & 32.51 & 31.86 & $(15.88-36.03)$ & & & & \\
\hline $\mathrm{MgO}$ & 17.71 & 21.85 & $(0.24-24.60)$ & 25.94 & 11.87 & $(0.01-30.60)$ & & & & 0.19 & 0.01 & $(0.01-6.38)$ & 0.22 & 0.01 & 0.02 & $(0.00-1.38)$ \\
\hline $\mathrm{CaO}$ & 11.52 & 1.08 & $(0.75-27.35)$ & 0.08 & 0.06 & $(0.00-1.08)$ & 3.20 & 8.71 & $(2.25-9.87)$ & & & & & & & \\
\hline $\mathrm{MnO}$ & 0.20 & 0.43 & $(0.00-0.59)$ & 0.09 & 0.04 & $(0.01-17.09)$ & & & & 0.34 & 0.35 & $(0.08-0.70)$ & 0.34 & 0.00 & 0.06 & $(0.00-1.26)$ \\
\hline $\mathrm{FeO}$ & 10.48 & 16.61 & $(0.25-18.27)$ & 9.44 & 25.89 & $(7.99-28.33)$ & 0.03 & 0.31 & $(0.00-1.16)$ & 39.48 & 56.49 & $(25.49-64.66)$ & 10.69 & 64.47 & 5.20 & $(0.39-66.86)$ \\
\hline $\mathrm{NiO}$ & & & & & & & & & & 0.23 & 0.38 & $(0.11-1.36)$ & & & & \\
\hline $\mathrm{ZnO}$ & & & & & & & & & & 13.03 & 0.52 & $(0.24-13.03)$ & & & & \\
\hline $\mathrm{Na} 2 \mathrm{O}$ & 0.31 & 0.12 & $(0.01-0.86)$ & 0.44 & 0.00 & $(0.00-1.81)$ & 9.69 & 5.08 & (3.26-9.69) & & & & & & & \\
\hline K2O & 0.06 & 0.10 & $(0.00-0.17)$ & 0.71 & 0.01 & $(0.00-1.79)$ & 0.12 & 0.40 & $(0.06-2.53)$ & & & & & & & \\
\hline Total & 96.87 & 96.73 & & 84.31 & 84.39 & & 98.97 & 98.18 & & 87.71 & 92.66 & & 85.37 & 90.38 & 88.79 & \\
\hline$\S$ & & & & & & & & & & & & & & & & \\
\hline $\mathrm{Si}$ & 7.76 & 7.89 & & 3.04 & 2.69 & & 11.46 & 10.12 & & & & & & & & \\
\hline $\mathrm{Ti}$ & 0.04 & 0.02 & & 0.00 & 0.00 & & & & & 0.12 & 0.47 & & & & & \\
\hline $\mathrm{Al}$ & 0.35 & 0.20 & & 2.11 & 2.39 & & 4.52 & 6.03 & & 0.51 & 0.25 & & & & & \\
\hline $\mathrm{V}$ & & & & & & & & & & 0.05 & 0.09 & & & & & \\
\hline $\mathrm{Cr}$ & 0.00 & 0.00 & & 0.00 & 0.00 & & & & & 8.64 & 7.85 & & & & & \\
\hline $\mathrm{Fe} 3+$ & & & & & & & 0.00 & 0.05 & & 6.60 & 7.25 & & & & & \\
\hline $\mathrm{Mg}$ & 3.78 & 4.66 & & 3.92 & 1.80 & & & & & 0.10 & 0.01 & & & & & \\
\hline $\mathrm{Ca}$ & 1.77 & 0.17 & & 0.01 & 0.01 & & 0.61 & 1.70 & & & & & & & & \\
\hline $\mathrm{Mn}$ & 0.02 & 0.05 & & 0.01 & 0.00 & & & & & 0.10 & 0.09 & & & & & \\
\hline $\mathrm{Fe}$ & 1.26 & 1.99 & & 0.80 & 2.20 & & & & & 4.50 & 7.47 & & & & & \\
\hline $\mathrm{Ni}$ & & & & & & & & & & 0.06 & 0.10 & & & & & \\
\hline $\mathrm{Zn}$ & & & & & & & & & & 3.24 & 0.12 & & & & & \\
\hline $\mathrm{Na}$ & 0.09 & 0.03 & & 0.09 & 0.00 & & 3.34 & 1.79 & & 0.00 & 0.00 & & & & & \\
\hline K & 0.01 & 0.02 & & 0.09 & 0.00 & & 0.03 & 0.09 & & 0.00 & 0.00 & & & & & \\
\hline $\begin{array}{l}\text { Total } \\
\text { cations }\end{array}$ & 15.08 & 15.02 & & 10.07 & 9.09 & & 19.97 & 19.78 & & 23.91 & 23.70 & & & & & \\
\hline
\end{tabular}

$\S$ Calculations on the basis of: $(15-\mathrm{Na}, \mathrm{K})$ or $(13-\mathrm{K}, \mathrm{Na}, \mathrm{Ca})$ cations for amphiboles; 32 oxygens for plagioclases and spinels and 14 oxygens for chlorites

$\mathrm{N}=$ number of examined samples; $n=$ number of analyses. 


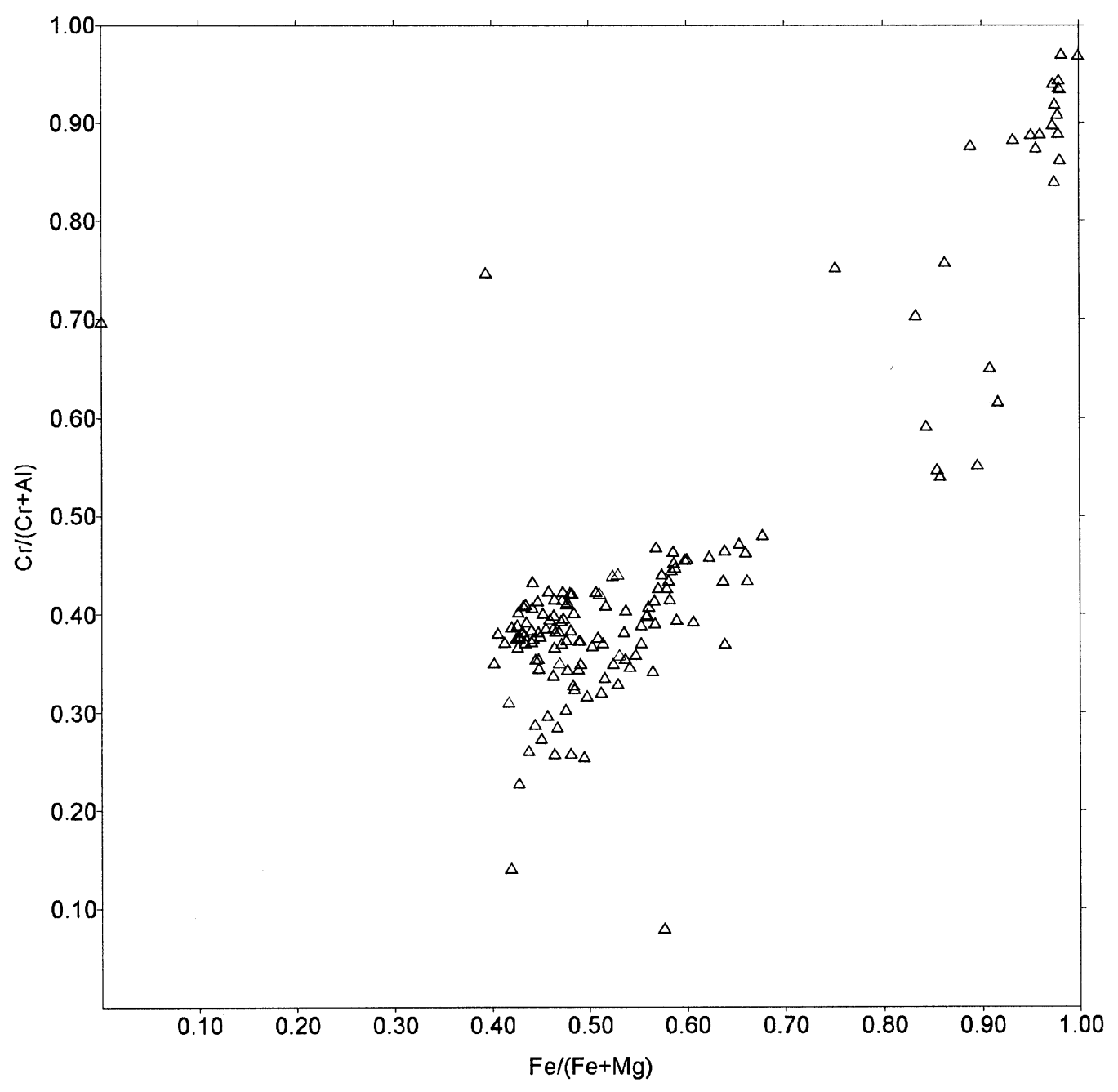

Fig. 4. $\mathrm{Cr} /(\mathrm{Cr}+\mathrm{Al})-\mathrm{Fe} /(\mathrm{Fe}+\mathrm{Mg})$ plot of BAOC Cr-spinels. Points plotting above $\mathrm{Cr} /(\mathrm{Cr}+\mathrm{Al})=0.50$ and above $\mathrm{Fe} /(\mathrm{Fe}+\mathrm{Mg})=0.70 \mathrm{represent}$ altered spinels included in strongly metasomatised samples.

theoretical high-temperature isopleth corresponding to the coexisting olivine compositions [23]. Spinels included in wehrlites/troctolites and in clinopyroxene-rich rocks, show the largest deviation to the right and plot in an elongated region instead of in a more or less circular and restricted region as is the case for spinels included in peridotites.

Ilmenite occurs only in gabbroic rocks and is not stoichiometric, having excess iron, low titanium and significant amounts of vanadium. In the structure of ideal ilmenite, $\mathrm{FeTiO}_{3}, \mathrm{Fe}^{2+}$ and $\mathrm{Ti}^{4+}$ occupy two distinct sets of $6 c$ equipositions corresponding to alternate octahedral layers in the hexagonal close-packing sequence of the anions along [001]. Single crystal X-ray diffraction shows that one of these sets of octahedral layers is fully occupied by iron while the other set of layers, the Ti layers of the ideal ilmenite structure, is partially occupied by iron. Confirming an $\mathrm{Fe}$ content larger than in ideal $\mathrm{FeTiO}_{3}$, the $\mathrm{c}_{0}$ lattice parameter is also greater than the ideal value [24] thus indicating solid solution of hematite ( $8 \%$ hematite, accord- ing to data presented in Lindsley [25]). Mössbauer spectra also confirm the presence of $\mathrm{Fe}^{3+}$ in the Fe-rich ilmenite. A typical spectrum of an ilmenite concentrate, taken at $61 \mathrm{~K}$, is represented in Fig. 5. The spectrum shows the presence of the doublets due to $\mathrm{Fe}^{3+}$ and $\mathrm{Fe}^{2+}$ in the ilmenite structure, as well as Al-Ti substituted hematite and $\mathrm{Fe}^{2+}$ in the structure of silicates 247. Hematite is present as bulk material. No hematite exsolution was observed microscopically and there is no X-ray diffraction evidence for superstructures due to periodic intercalation of consecutive hematite-like layers (layers fully occupied by $\mathrm{Fe}$ ) within the ilmenite crystal structure.

In deformed gabbros, plagioclase usually displays conspicuous zonation with cores of $\mathrm{An}_{60}-\mathrm{An}_{70}$ composition (that is, the normal composition of BAOC plagioclases) surrounded by anorthite-poor rims of the same (oligoclase) composition as non-twinned and undeformed plagioclase aggregates filling late irregular microfractures and many segregation bands within the primary plagioclase grains. 


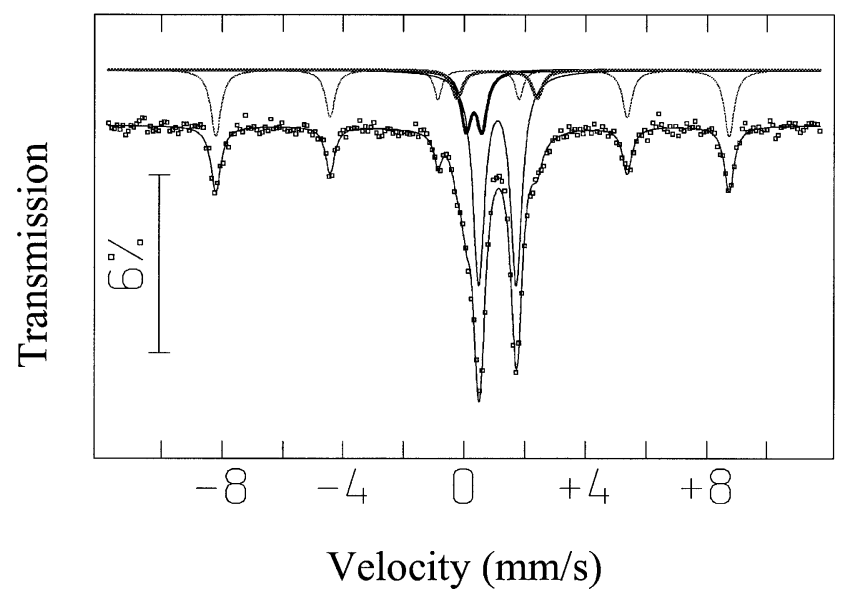

Fig. 5. Mössbauer spectrum of a BAOC ilmenite concentrate, taken at $61 \mathrm{~K}$. The thick gray line component is due to $\mathrm{Fe}^{2+}$ in silicates and the magnetic sextet (thin gray line) is due to Al,Ti-substituted hematite. The two doublets plotted with black lines correspond to $\mathrm{Fe}^{3+}$ (thick line) and to $\mathrm{Fe}^{2+}$ (thin line) in the ilmenite structure.

In the gabbroic rocks of BAOC, primary amphiboles are corroded brown hornblendes characterised by significant concentrations of sodium. Later amphiboles, formed during Variscan metamorphism, are typically magnesium-rich hornblendes, sometimes surrounding relic primary pyroxene grains, grading to actinolite-tremolite compositions as metamorphic temperatures decreased. Chlorite composition also differs according to the context of precipitation: chlorite coeval with the late serpentinisation pulses of wehrlites/troctolites is tri-octahedral and iron-poor, whereas chlorite deposited during carbonatisation along the regional shear zones is mainly di-octahedral (maximum octahedral occupancy 2.5) and has $\mathrm{Fe} /(\mathrm{Fe}+\mathrm{Mg})$ ratios up to 0.6.

Metasomatism (serpentinisation and carbonatisation) does not lead to complete decomposition of the primary Cr-spinel, but the composition of this mineral is strongly altered during the process. The alteration may be thought of as an aluminium and magnesium leaching (that in some locations proceeds to completion), accompanied by considerable oxidation of the iron left behind and sometimes by significant zinc incorporation. In some wholly carbonatised rocks, petrographic observations and electron microprobe data show the presence of completely and homogeneously altered grains of spinel, with total leaching of $\mathrm{Al}$ and $\mathrm{Mg}$ and a stoichiometrically estimated $60 \%$ of the iron atoms in the $\mathrm{Fe}^{3+}$ state. Mössbauer spectra measured between room temperature and $6 \mathrm{~K}$ show that there are several different spinels present which can be distinguished by the amount of $\mathrm{Fe}^{3+}$ that each one contains and by their different magnetic ordering temperatures [26]. A typical spectrum, taken at $172 \mathrm{~K}$, is represented in Fig. 6, showing several contributions. The sextet with the largest magnetic splitting is due to Al,Ti-substituted hematite. The remaining contributions are due to $\mathrm{Fe}$ in chromite grains. Both sextets with lower magnetic splittings than hematite are attributed to magneti-

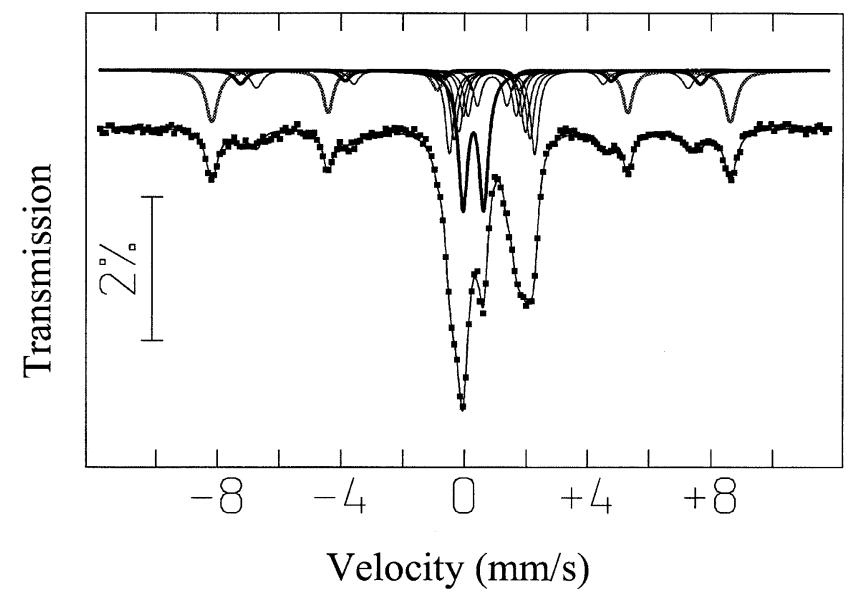

Fig. 6. Mössbauer spectrum of a BAOC $\mathrm{Cr}$-spinel concentrate, taken at $172 \mathrm{~K}$. The thick grey line component is due to Al,Ti-substituted hematite. Both sextets with lower magnetic splittings than hematite are attributed to magnetically ordered chromite. The doublet represented as a black thick line, and the distribution of doublets represented as black thin lines, are due, respectively, to octahedral $\mathrm{Fe}^{3+}$ and tetrahedral $\mathrm{Fe}^{2+}$ in paramagnetic chromite.

cally ordered chromite. All doublets are due to $\mathrm{Fe}$ in paramagnetic chromite, the one represented as a black thick line to octahedral $\mathrm{Fe}^{3+}$ and the rest to tetrahedral $\mathrm{Fe}^{2+}$. The spectra indicate that the dominant spinel types are those which are paramagnetic down to $6 \mathrm{~K}$ and have a lower amount of $\mathrm{Fe}^{3+}$, i.e., a significant part of the chromite grains is still well preserved even in severally carbonatised rocks. Mössbauer data, therefore, seem to indicate that $\mathrm{Cr}$-spinel partially withstood severe carbonatisation of its host rocks and that several stages of alteration/oxidation may be simultaneously present in the most altered samples.

Evidence for ilmenite alteration is widespread. In deformed but unmetasomatised rocks, ilmenite is partly preserved, but some of its grains have been replaced by a crypto-crystalline aggregate of unidentified minerals, whose global chemical composition as determined by electronmicroprobe analysis is Fe-poor and includes considerable amounts of both $\mathrm{Ca}$ and $\mathrm{Si}$, in agreement with the observation that plagioclase is being recrystallised with a more sodian composition and quartz (as very fine matricial aggregates) is being precipitated. In metasomatised rocks, no ilmenite is preserved and most of the former ilmenite grains are now pseudomorphic aggregates of ill-crystallised titanium minerals, the remainder having been replaced by Ti-bearing hematite. Mössbauer spectroscopy and X-ray diffraction indicate that the mechanism leading to ilmenite decomposition is iron oxidation. No evidence for hematite intergrowths in the ilmenite structure was found. However ilmenite seems to be present in different stages of alteration. The average oxidation degree, $19 \%$ of the total $\mathrm{Fe}$ as $\mathrm{Fe}^{3+}$, is being achieved by accomodating the excess $\mathrm{Fe}$ in the $\mathrm{Ti}$ layers of the pure primary ilmenite. When the oxidation degree of Fe becomes too large, the ilmenite crystal struc 
ture seems to disrupt as suggested by the large number of polycrystalline and poorly crystallized grains found. $\mathrm{Fe}$ is segregated and forms $\mathrm{Ti}$ containing hematite which is always present as a decomposition product, even when pure separates of the pseudomorphs after ilmenite are taken for analysis. Finally, it should be stressed that both Mössbauer spectroscopy and X-ray diffraction reveal that «fresh» ilmenite included in undeformed and unmetasomatised rocks is really altered, all samples examined showing several grains of the mineral replaced by a mixture of hematite and titanium minerals. This is taken to represent the effects of Tertiary weathering and must be taken into account if mineral exploration for ilmenite is to be undertaken in BAOC.

\subsection{Shearing within BAOC}

The structure of BAOC is fairly complicated. The massive character of its rock units does not allow fold development, but the whole of BAOC is cut by several types of non-coeval tectonic accidents. Most visible in the geological maps are late NNE-SSW to NE-SW left-handed faults, usually ascribed to the late phases of the Variscan deformation, that cut all rock units and tectonic features of BAOC, and major E-W to WNW-ESE faults, of very complex evolution, that separate BAOC from the adjoining geological domains and are responsible for the main features of its present day architecture. Also important are brittle ENEWSW shear zones, that may form complex structural arrays with the E-W to ESE-WNW accidents and some N-S to NW-SE right-handed faults, commonly interpreted as the conjugate system of the late Variscan tectonic accidents mentioned above.

The detailed study of the mineral infillings and of the hydrothermal alteration associated to the E-W to WNWESE shear zones [21] shows that they were initially formed as semi-ductile shear zones during the waning stages of the Variscan metamorphism and continued to develop as brittle fault zones as deformation and metasomatism related to the Variscan continental collision proceeded to completion. Each shear zone is composed of several parallel and anastomosed left-handed accidents with a significant souththrusting component, whose main traces have the same general strike as the cartographic expression of the whole shear zone and cut earlier, ductile-semiductile, pure lefthanded strike-slip, N140-N145 shear zones, which are at present almost obliterated and show no or only incipient carbonatisation coeval with their nucleation and propagation. Several minor families of movement planes can be seen inside each shear zone, the significance of which is difficult to ascertain, although most orientations, styles of deformation and mineral infillings allow their interpretation as conjugates of the main systems or as secondary fractures formed at the tips of the propagating main shear zones.

The Ferreira-Ficalho thrust is also a left-handed, souththrusting WNW-ESE tectonic accident, but it is a special case among the E-W to WNW-ESE shear zones because its lateral continuity is exceptional, and its associated carbonatisation is exclusively calcitic. So, although the FerreiraFicalho Thrust is at present a major accident separating two very different geological domains, comparison with the remaining shear zones of similar orientation within BAOC seems to indicate that it is a late accident with a comparatively simple evolution.

Detailed structural data on the whole of BAOC rocks has been summarised by Quesada et al. [2] and shall not be repeated here. Overall, tectonic deformation of BAOC is strongly concentrated in the shear zones, but internal deformation is clearly present in rocks away from the tectonic accidents. In fact, in several portuguese locations [13], a penetrative north-verging tectonic fabric is preserved in the lower gabbroic section and is carried by the high temperature metamorphic paragenesis already mentioned. Also, many gabbroic rocks display a well marked stretching lineation formed by the alignment of green hornblende/actinolite crystals, precipitated during paroxysmal Variscan greenschist-amphibolite facies metamorphism. This last lineation is the one geometrically compatible with the magmatic fabrics observed in primitive gabbros of BIC.

\section{Geodynamic evolution of BAOC an adjoining areas}

As shown by their chemical composition and by what remains of their original mineral paragenesis, BAOC rocks were formed in an oceanic setting, probably in a back-arc basin originating as normal oceanic lithosphere was being subducted under the Ossa-Morena Zone.

Although the available evidence is very scant and somewhat controversial, there seems to have been progressive magma mixing in some places during the original crystallisation of BAOC ultramafics. This is bore out by the observation that BAOC ultramafics can be divided in two subgroups: the first one includes mainly harzburgites and dunites and contains Ni-bearing olivine and Cr-spinel of homogeneous compositions; the second one, consisting of clinopyroxene-rich peridotites and of troctolites/wehrlites, is characterised by the presence of Ni-poor olivine, of high-temperature sulphide minerals and of $\mathrm{Cr}$-spinel of variable chemical composition. The admixing magma causing the chemical variability of Cr-spinel [27] would also have carried (due to crustal contamination in an arc environment?) the sulphur needed to precipitate the sulphide minerals which sequestered the nickel that otherwise would have been incorporated in the olivine structure.

Shortly after initial crystallisation, and still at very high residual magmatic temperatures, BAOC was obducted over the Ossa-Morena Zone along a presently not observable shear zone. Evidence for this obduction exists as small internal sub-horizontal, north-verging shears and as a recrystalisation anisotropic fabric preserved in the lower gabbroic sequence and carried by the very high temperature 
metamorphic paragenesis. Normal regional metamorphism may be ruled out as the origin for this metamorphic texture, because no evidence for it is ever found above the lower gabbroic section; a similar absence in the underlying peridotites, where the anisotropic stresses induced by obduction at the base of the ophiolitic nappe should be at their maximum, is easily explained by later serpentinisation obliteration. Further record of this obduction-induced recrystallisation is found in the compositional «mismatch» between $\mathrm{Cr}$-spinel and olivine, the latter being too forsteritic for the observed composition of the spinel, if equilibrium co-crystallisation of both at normal magmatic temperatures is assumed. Chemical equilibrium at the actual chemical compositions of both minerals can be achieved at significantly lower temperatures, but no other mineralogical evidence for such lower crystallisation temperatures exists and thus the present compositions must record a subsolidus reequilibration of $\mathrm{Cr}$-spinel and olivine.

Obduction also lead to a geologically sudden chilling of BAOC. Mineralogical evidence for this is the lack of further primary reequilibration of spinel, whose composition indicates a high closure temperature for the subsolidus reactions with olivine, and the lack of exsolution textures within ilmenite, which are to be expected if ilmenite with the observed composition were slowly cooled from normal basic magma temperatures. The hematite peaks systematically observed in X-ray powder diffractograms cannot be taken as evidence for crypto-exsolution textures within ilmenite, because of the simultaneous presence of petrographically invisible rutile and pseudorutile, which indicates decomposition of ilmenite in supergene conditions. Modelling (see appendix for details), assuming conduction as the only means of heat transfer, of the thermal evolution of BAOC after obduction, shows that the obducted hot slab cools down in a few hundred thousand years and causes negligible heating of the overthrusted continental crust (Figs 7 and 8). The results obtained by running such simple model must be regarded as conservative, because no attempt is made to model possible and far more efficient mechanisms of heat transfer involving fluid circulation, which is still poorly understood at the ductile regimes suggested by the high temperatures needed to account for the metamorphic paragenesis. It seems thus improbable that BAOC obduction is recorded as a thermal metamorphic event in the rocks of the autochthonous Ossa-Morena Zone or that heat transfer from BAOC caused the fluid releases (from decomposition of the underlying carbonate platform, for instance), whose circulation is attested by the later intense metasomatism associated to BAOC internal shear zones. The model also excludes the possibility that the observed greenschistamphibolite facies is a record of the late stages of the obduction event.

The greenschist-amphibolite metamorphism is a regional event that affects BAOC and most of the geological units surrounding it, BIC intrusives being the outstanding exception. By the time of this metamorphic event, the deforma- tion style of BAOC had changed substantially: instead of north verging internal shear zones, BAOC now shows very important WNW-ESE left-lateral shears with almost no vertical movement ( $\mathrm{D}_{2}$ deformation phase), and displays, at the gabbroic rocks level, a prominent stretching lineation materialised by the metamorphic newly formed green hornblende-actinolite crystals. There is also some evidence [13.2] for west thrusting along N-S shear zones, which is geometrically compatible with the stress field that originated the WNW-ESE shears and with the linear fabric displayed by the gabbroic rocks. As the detailed study of the main shear zones shows, this tectono-metamorphic regime gradually changed with time. Gradually decreasing temperatures are recorded (mineralogically and texturally) within the alteration zones lining up the shear zones and, at the same time, the shears gradually entered the brittle deformation regime and acquired an ever increasing SWverging thrust component. The final stage of this varying tectono-metamorphic process may be described as a greenschist or lower facies metamorphism accompanying brittle SW-verging thrusts along the earlier strike-slip shear zones ( $\mathrm{D}_{3}$ deformation phase), themselves object of intense carbonate (mainly calcitic) metasomatism.

The geometrical compatibility between the $\mathrm{D}_{2}$ linear fabric of BAOC and the primary fabrics of the primitive gabbros of BIC deserves attention and is a clear indication of a non-synchronous origin for both igneous bodies. As a matter of fact, the fabrics are carried in BAOC by a metamorphic paragenesis indicating low amphibolite/greenschist facies temperatures, and in BIC by an igneous paragenesis indicating normal primitive gabbro crystallisation temperatures. The simpler interpretation seems to be a postulated synchrony between the $\mathrm{D}_{2}$ defor mation phase of BAOC and the initial stages of BIC intrusion. BIC would thus be the intrusives related to the continental collision recorded in this segment of the Variscan orogen. This is coherent with the observation that $\mathrm{D}_{3}$ structures, and its associated metamorphism, as revealed in BAOC shear zones, are observed in very large regions of both the Ossa-Morena and the South Portuguese zones in a seemingly deformational and metamorphic continuum.

It is worth noting that, although three deformation phases have been described for BAOC (e.g. [13,2]), all of them generated macrostructures whose orientations are compatible with a general NE-SW compression typical of the Variscan Orogen in South Portugal and Southwest Spain. The whole of BAOC evolution can thus be envisaged as a single geodynamic cycle of continental approach and collision, wherein obduction is just a minor event in the period preceding climactic deformation and metamorphism; the present geological record documents mainly the waning stages following that paroxysmal phase. Also worth mentioning is the fact that, at least in its portuguese tract, BAOC evolved in a dry environment until metamorphic degassing caused the influx of water and, later, of water- $\mathrm{CO}_{2}$ fluids. In fact, significant amounts of water did not enter BAOC 

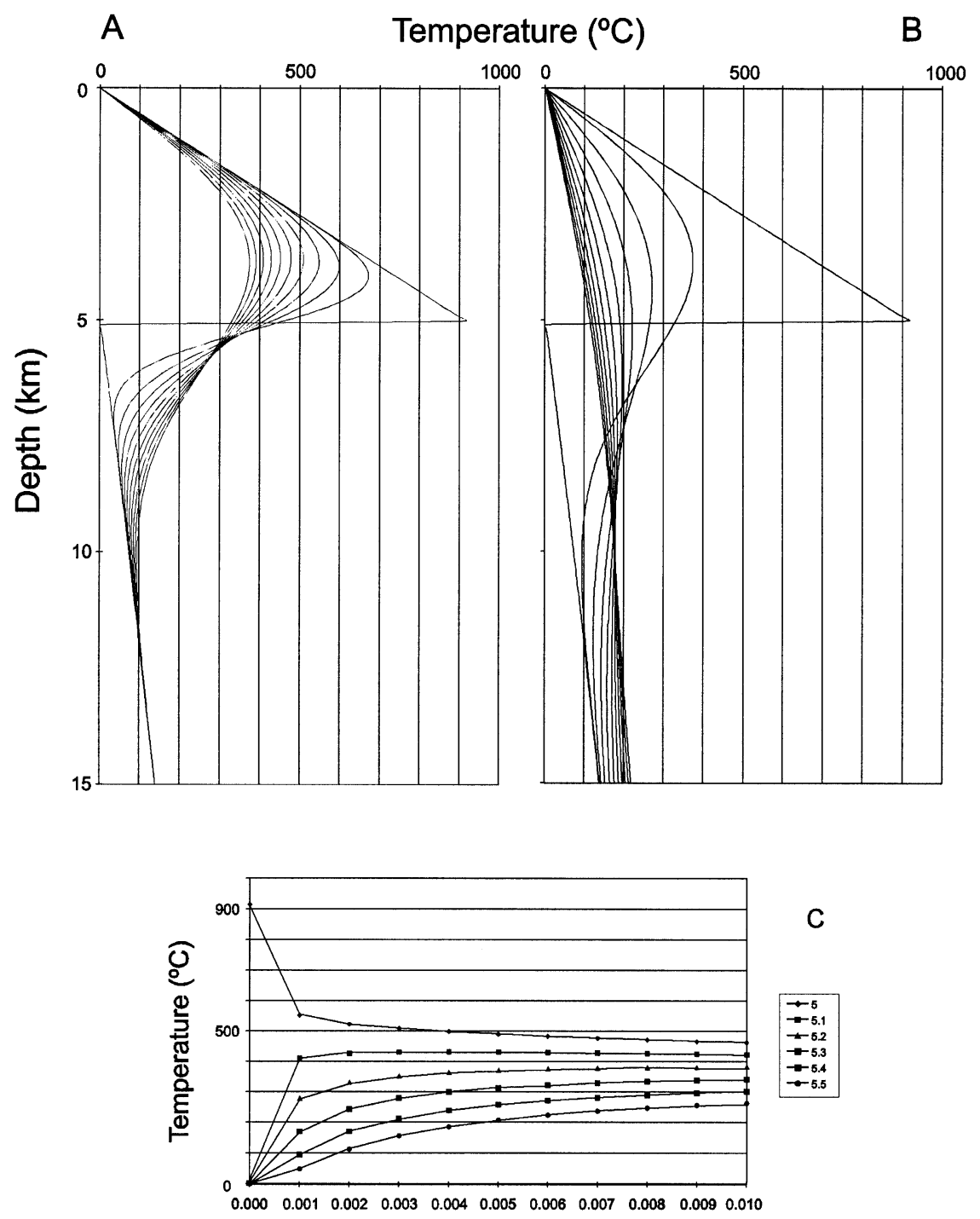

\section{C}
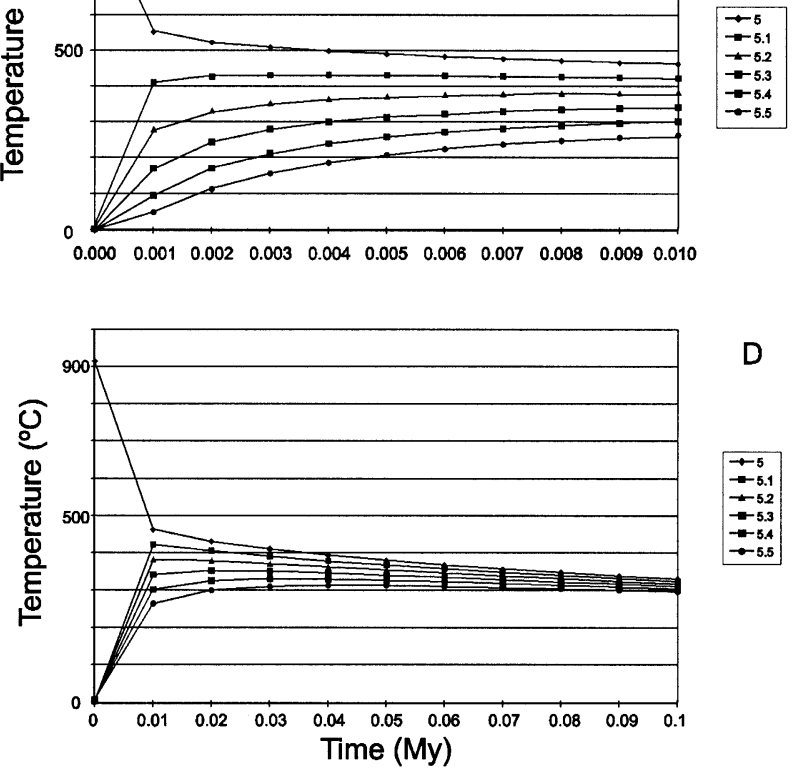

D

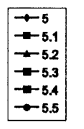

Fig. 7. Numerical modelling of the post-obduction thermal evolution of $\mathrm{BAOC}$ and underlying rocks, considering a normal geothermal gradient within $\mathrm{BAOC}$ and a basal temperature of $920^{\circ} \mathrm{C}$. A - Geotherms plotted every 10000 years between 0 and 100000 years. B - Idem, plotted every 100000 years, between 0 and $10^{6}$ years. $\mathbf{C}$ - Modelled thermal evolution of the carbonate sequence immediately underlying BAOC; T-t lines are drawn every $0.1 \mathrm{~km}$ for the first 10000 years after obduction. D - Idem for the first $0.1 \mathrm{My}$.

before extensive peridotite serpentinisation occurring during the initial stages of WNW-ESE shear zone development. Prior obduction-related recrystallisation of gabbros was anhydrous and their subsequent amphibolite-facies metamorphism was far from complete. Since oceanic serpentini- sation did not occur prior to obduction, this may be taken as yet another indication that BAOC was composed of very young rocks at the time of obduction or that ocean water circulation was restricted to levels above the present erosion surface. 


\section{Temperature $\left({ }^{\circ} \mathrm{C}\right)$}
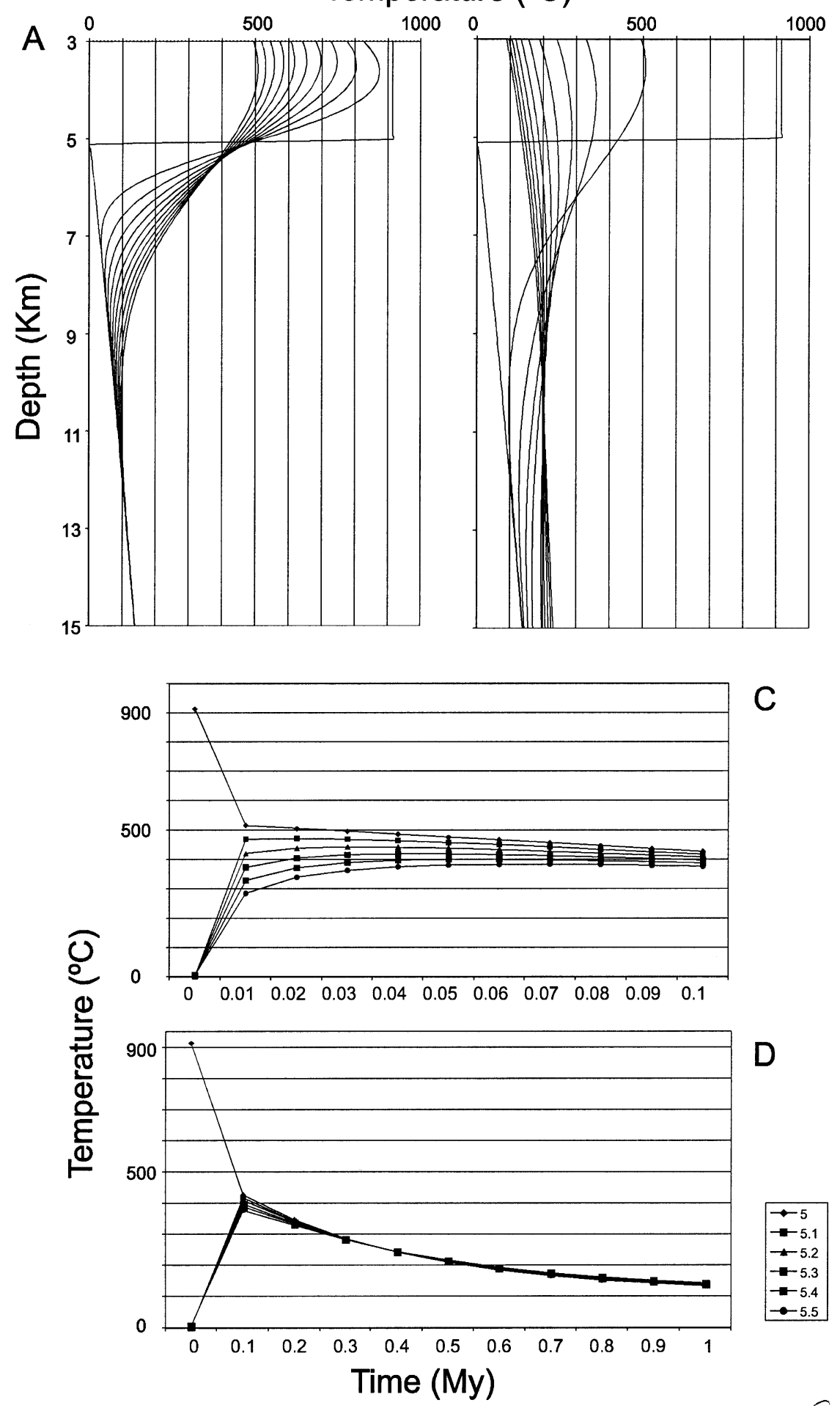

Fig. 8. Numerical modelling of the post-obduction thermal evolution of BAOC and underlying rocks, considering a basal slab of uniform temperature equal to $920^{\circ} \mathrm{C}$ within BAOC. A - Geotherms plotted every 10000 years between 0 and 100000 years. B - Idem, plotted every 100000 years, between 0 and $10^{6}$ years. C - Modelled thermal evolution of the carbonate sequence immediately underlying BAOC; T-t lines are drawn every $0.1 \mathrm{~km}$ for the first 100000 years after obduction. D - Idem for the first 1 My.

\section{- Appendix 1}

The modelling of the thermal evolution of the crustal section after BAOC emplacement was treated as a one dimensional problem where a sequence of oceanic crustal rocks of $5 \mathrm{~km}$ thick is put upon a stretched crustal section some $20 \mathrm{~km}$ thick. The base of the thrust is set to 800 to 900 ${ }^{\circ} \mathrm{C}$ range in agreement with field data on the temperature of 
Table A1

Variable definitions

\begin{tabular}{lll}
\hline Variable & Definition & Units (SI) \\
\hline$A$ & Volumetric heat production & $\mathrm{W} \mathrm{m}^{-3}$ \\
$C$ & Heat capacity & $\mathrm{J} \mathrm{kg}^{-1} \mathrm{~K}^{-1}$ \\
$h_{r}$ & Characteristic distance & $\mathrm{m}$ \\
$h_{s}$ & Mass heat production in the crust & $\mathrm{W} \mathrm{kg}$ \\
$k$ & Thermal conductivity & $\mathrm{W} \mathrm{m} \mathbf{K}^{-1}$ \\
$q_{m}$ & Conductive heat flux & $\mathrm{W} \mathrm{m}{ }^{-2}$ \\
$T$ & Temperature & $\mathrm{K}$ \\
$T_{s}$ & Surface temperature & $\mathrm{K}$ \\
$t$ & Time & $\mathrm{s}$ \\
$z$ & Depth & $\mathrm{m}$ \\
$\kappa$ & Thermal diffusivity & $\mathrm{m}^{2} \mathrm{~s}^{-1}$ \\
$\varrho$ & Density & $\mathrm{Kg} \mathrm{m}^{-3}$ \\
\hline
\end{tabular}

thrust emplacement. Thermal gradients for both crustal blocks were calculated according to the equation [2] (see Table A1 for the variable definitions):

$$
T=T_{s}+\frac{q_{m} z}{k}+\frac{\rho H_{s} h_{r}^{2}}{k}\left(1-e^{-z / h_{r}}\right)
$$

The heat flux was adjusted to obtain a basal temperature of BAOC of $920^{\circ} \mathrm{C}$, and an approximate geothermal gradient in the range $10-20^{\circ} \mathrm{C} . \mathrm{Km}^{-1}$ for the autochthon crustal rocks. The mean thermal conductivity of the continental crust and ophiolite was calculated using data given for the considered rock types in Appendix 2 of Turcotte and Schubert 29], and weighted according to the volumes of each rock type in the crustal block. Mean densities were calculated in the same way for both blocks and the values used for the mass heat production due to radioactive elements $\left(H_{s}\right)$ were calculated as a function of their mean concentration in the upper continental crust and oceanic crust. The characteristic distance used for both blocks was $10 \mathrm{Km}$ in agreement with the general knowledge on radioactive element concentration in the crust. Surface temperature was arbitrarily set to zero. Both these data values (densities and radioactive heat production) were consulted in Carmichael [30]

The initial conditions assume an instantaneous thickening of the crust with no heat lost. The model calculates the variation of the temperature of the crustal section with time, in one-dimension by solving numerically the heat conduction equation

$$
\frac{\partial T}{\partial t}=\kappa \frac{\partial^{2} T}{\partial z^{2}}+\frac{A}{\rho C}
$$

The boundary conditions for the base of the crustal section admits a constant heat flux of $0.03 \mathrm{~W} \cdot \mathrm{m}^{-2}$, which sets a constant thermal gradient of nearly $13{ }^{\circ} \mathrm{C} / \mathrm{Km}$ at the base of the crust, according to the equation (Fourier law)

$$
q_{m}=k \frac{d T}{d z}
$$

The top of the crustal section is kept at the constant temperature of $0^{\circ} \mathrm{C}$. The model does not calculate any heat loss mechanism other than conduction. This rules out the possibility of convective heat loss as well rendering the calculations rather conservative. However, the high temperatures involved suggest a predominant ductile regime and fluid circulation in such conditions is very ill-known, so it has been discarded for this reason. The involvement of fluids is expected to be more important in the later cooling stages of the crustal section. Two sets of runs were performed for a maximum period of $1 \mathrm{Ma}$, where different temperature profiles were assumed for the BAOC section: i) a normal gradient from surface to the base of the oceanic crust at $920^{\circ} \mathrm{C}$; ii) the same gradient but keeping the lower $2 \mathrm{Km}$ of the oceanic crust at $920^{\circ} \mathrm{C}$, just as a sub-solidus hot magmatic chamber.

\section{References}

[1] A. Ribeiro, C. Quesada, R.D. Dallmeyer, Geodynamic evolution of the Iberian Massif, in: R.D. Dallmeyer, E. Martínez García (Eds.), Pre-Mesozoic Geology of Iberia, Springer-Verlag, 1990, pp. $398-409$.

[2] C. Quesada, P.E. Fonseca, J. Munhá, J. Oliveira, A. Ribeiro, The Beja - Acebuches Ophiolite (Southern Iberia Variscan foldbelt): geological characterization and geodynamic significance, Bol. Geol. y Minero de España 105 (1) (1994) 3-49.

[3] A.S. Andrade, Sur l'age des orthogneiss d'Alcáçovas (Alentejo) et des filons (basiques et acides) qui les recoupent, Mem. Not. Museu Lab. Mineral. Geol. Univ. Coimbra 18 (1974) 29-36.

[4] A.S. Andrade, (massif de Beja)Remarques sur le chimisme des gabbros d'Odivelas, Mem. Not. Publ. Mus. Lab. Mineral. Geol. Univ. Coimbra 81 (1976) 75-84.

[5] A.S. Andrade, Contribution à l'analyse de la suture hercyniènne de Beja (Portugal), perspectives métallogéniques. PhD thesis, INPL, Nancy, 1983.

[6] J. Munhá, J.T. Oliveira, A. Ribeiro, V. Oliveira, C. Quesada, R. Kerrich, Beja-Acebuches Ophiolite characterization and geodynamic significance, Maleo 2 (13) (1986) 31-31.

[7] J. Munhá, A. Ribeiro, P.E. Fonseca, J. Oliveira, P. Castro, C. Quesada, Accreted terranes in Southern Iberia: the Beja-Acebuches ophiolite and related oceanic sequences, $28^{\text {th }}$ Internat, Geol. Congr. Abstr. With Progr. 2 (1989) 481-482.

[8] P.E. Fonseca, A. Ribeiro, Tectonics of the Beja-Acebuches ophiolite: a major suture in the Iberian Variscan foldbelt, Geol. Rundsch. 82 (1993) 440-447.

[9] J.F. Santos, Petrologia do sector ocidental da Unidade de Odivelas (maciço de Beja), M. Sc. Thesis, Univ. Aveiro, 1990.

[10] J.F. Santos, A. Andrade, J. Munhá, Magmatismo orogénico varisco no limite meridional da Zona de Ossa-Morena, Comunic. Serv. Geol. Portugal 76 (1990) 91-124.

[11] J.B. Silva, Transpressive tectonics during the Pre-Mesozoic Cycles in the West Iberia, XIII Reunião de Geol. Oeste Peninsular - Annual PICG-376 Meeting, Vila Real (1997) 237-243.

[12] J.B. Silva, Geodinâmica ante-Mesozóica do sector Oeste da Zona de Ossa-Morena e regiões limítrofes com base em recentes observações, in: A. Araujo, E. Pereira (Eds.), Estudo sobre a Geologia da Zona de Ossa-Morena (Maciço Ibérico) - Homenagem ao Prof. Francisco Gonçalves, Univ. Évora, 1997, pp. 231-262.

[13] P.E. Fonseca, Estudo da sutura varisca no $S W$ ibérico, nas regiões de Serpa-Beja-Torrão e Alvito-Viana do Alentejo, PhD Thesis, Dept. Geologia, Fac. Ciências, Univ Lisboa, 1995, pp. 325. 
[14] P. Fonseca, J. Munhá, J. Pedro, F. Rosas, P. Moita, A. Araújo, N. Leal, Variscan ophiolites and high-pressure metamorphism in Southern Iberia, Ofioliti 24 (2) (1999) 259-268.

[15] S.S. Sun, R.W. Nesbitt, Petrogenesis of Archean ultrabasic and basic volcanics: evidence from rare earth elements, Contrib. Mineral. Petrol. 65 (1978) 301-325.

[16] F.A. Frey, Rare earth element abundances in upper mantle rocks, in: P. Henderson (Ed.), Rare Earth Element Geochemistry, Developments in Geochemistry 2, Elsevier, 1986, pp. 153-203.

[17] J.A. Pearce, J.R. Cann, Ophiolite origin investigated by discriminant analysis using Ti, Zr and Y, Earth and Planet. Sci. Lett. 12 (1971) 339-349.

[18] J.A. Pearce, M.J. Norry, Petrogenetic implications of Ti, Zr, Y and $\mathrm{Nb}$ variations in volcanic rocks, Contrib. Mineral. Petrol. 69 (1979) S33-S47.

[19] J.W. Shervais, Ti-V plots and the petrogenesis of modern and ophiolitic lavas, Earth Planet. Sci. Lett. 59 (1982) 101-118

[20] L. Beccaluva, D. Ohnenstetter, M. Ohnenstetter, Geochemical discrimination between ocean-floor and island-arc tholeiites - application to some ophiolites, Can. J. Eart Sci. 16 (1979) 1874-1882.

[21] A. Mateus, J. Figueiras, M. Gonçalves, P. Fonseca, Evolving fluid circulation within the variscan Beja-Acebuches ophiolite complex (SE Portugal), Ofioliti 24 (2) (1999) 269-282.
[22] P.L. Roeder, Chromite: from the fiery rain of chondrules to the Kilauea Iki lava lake, Can. Mineral. 32 (1994) 729-746.

[23] H.J.B. Dick, T. Bullen, Chromian spinel as a petrogenetic indicator in abyssal and alpine-type peridotites and spatially associated lavas, Contrib. Mineral. Petrol. 86 (1984) 54-76.

[24] Waerenborgh et al. in press.

[25] D.H. Lindsley, The crystal chemistry and structure of oxide minerals as exemplified by the Fe-Ti oxides, in: D. Rumble III (Ed.), Oxide Minerals. Reviews in Mineralogy, vol.3, BookCrafters, Inc., Chelsea, Michigan, USA, 1976

[26] Waerenborgh et al. submitted.

[27] P. Peltonen, Crystallization and re-equilibration of zoned chromite in ultramafic cumulates, Vammala Ni-belt, Southwestern Finland, Can. Mineral. 33 (1995) 521-535.

[28] R.D. Dallmeyer, P. Fonseca, C. Quesada, A. Ribeiro, ${ }^{40} \mathrm{Ar} /{ }^{39} \mathrm{Ar}$ mineral age constraints on the tectonothermal evolution of the variscan Suture in SW Iberia, Tectonophysics 222 (1993) 177-194.

[29] D.L. Turcotte, G. Schubert, Geodynamics. Application of continuum physics to geological problems, John Wiley \& Sons, New York, 1982.

[30] R.S. Carmichael, Practical handbook of physical properties of rocks and minerals, CRC Press, Boston, 1989. 